\title{
Parents' Initiation of Alcohol Drinking among Elementary and Kindergarten Students
}

\author{
Kazuko Eto ${ }^{1}$ and Masahiro Sugimoto ${ }^{2, *(D)}$ \\ 1 Department of Nursing, Yokohama Soei University, Yokoyama 226-0015, Japan; etokaguko@yahoo.co.jp \\ 2 Research and Development Center for Minimally Invasive Therapies, Institute of Medical Science, \\ Tokyo Medical University, Shinjuku, Tokyo 160-8402, Japan \\ * Correspondence: mshrsgmt@tokyo-med.ac.jp; Tel.: +81-3-3351-6141
}

Citation: Eto, K.; Sugimoto, M. Parents' Initiation of Alcohol Drinking among Elementary and Kindergarten Students. Children 2021, 8, 258. https://doi.org/10.3390/ children 8040258

Academic Editor: Laura Simons

Received: 21 December 2020

Accepted: 23 March 2021

Published: 27 March 2021

Publisher's Note: MDPI stays neutral with regard to jurisdictional claims in published maps and institutional affiliations.

Copyright: (c) 2021 by the authors. Licensee MDPI, Basel, Switzerland. This article is an open access article distributed under the terms and conditions of the Creative Commons Attribution (CC BY) license (https:// creativecommons.org/licenses/by/ $4.0 /)$.

\begin{abstract}
Parental experience of initiation of alcohol drinking has been identified as one of the early causes of alcohol drinking in preadolescents in many countries, including Japan. This study identified the association between parental alcohol-related knowledge and the initiation of alcohol use among preadolescent students in an urban area in Japan. Self-administrated questionnaires were distributed to 420 parents of kindergarteners and elementary school students, of which 339 were filled and returned (response rate: $81 \%$ ). The parents' experience in initiating alcohol drinking in their children and their knowledge about the effects of alcohol on youth were explored. The requirements for drinking prevention programs for youth were also investigated. The result showed that a significantly higher proportion of parents of elementary school students had experiences of initiating alcohol use in their children compared to parents of kindergarten children. The parents' knowledge regarding the effects of alcohol on youth showed no significant difference between the two parent groups. These data indicate that the age of children is the only factor as opposed to parents' knowledge. We also found significant differences in the requirements of prevention programs between the two parent groups. The results of this study can contribute to the design of alcohol prevention programs for these parents, which could reduce the onset of children's drinking.
\end{abstract}

Keywords: elementary school; kindergarten; alcohol use; parental factors; prevention programs

\section{Introduction}

Underage alcohol use is a serious problem associated with various health issues [1,2] and problem behaviors [3-5]. This problem is worldwide in its scope, although the prevalence varies across countries. In the United States, a high prevalence of alcohol intake among youth is reported by the National Survey Drug Use and Health [6]. In Asian countries, especially Thailand, Vietnam, and the Philippines, a high prevalence ratio of alcohol use has also been reported [7-9]. A similar prevalence rate has been reported in the urban areas of China within the past years [10]. Based on these reports, identifying students at risk of alcohol consumption [11], their parents' alcohol-related knowledge, and the development of effective prevention methods are necessary to reduce the prevalence of underage alcohol use in Japan.

Alcohol misuse negatively affects young people and has become one of the leading causes of premature death [12]. The precise age of drinking onset is associated with subsequent alcohol dependence as well as various other health problems. For example, among persons in the U.S. who started drinking alcohol before 14 years, 13\% became alcohol-dependent compared with only $2 \%$ of those who waited until they were 21 years or older [3,4]. Adolescent drinking does not only affect health but also causes maladaptive behavior, such as violence [13] and suicide [14]. Adolescents' alcohol drinking, smoking, and drug-use behavior are interdependent in such a way that when a person starts drinking alcohol, he/she may likely start smoking and using drugs [15,16]. A survey on senior high school students revealed strong positive correlations between the initiation of alcohol 
drinking, smoking, and sexual intercourse [17]. The above findings indicate the need to identify factors associated with preadolescent alcohol drinking.

Given the negative health effects of alcohol drinking at younger ages, a large number of studies have been conducted on alcohol-related drinking among adolescents. For instance, several studies have sought to find out behavioral problems associated with the early onset of drinking such as whether students who began drinking alcohol at early adolescence frequently engaged in delinquency in later adolescence [18]. In addition, many studies have investigated the effects of individual and environmental factors on alcohol drinking, smoking, and drug use among high school students and adolescents [7,11,17,19-25]. However, only a few studies are available on alcohol use among preadolescents (e.g., elementary school students aged from 6 to 12 in Japan) [26], and fewer studies have been conducted on parents' initiation of alcohol use among kindergarteners (age <5) in Japan. This view is supported by the review of proceedings of the Research Society on Alcoholism meeting in 2003, which indicated that only a few studies are available on the onset of alcohol drinking among elementary students [26]. Stemmed from these findings, the current study, which seeks to investigate parents' experience in initiating alcohol drinking and parents' alcohol-related knowledge with a focus on elementary and kindergarten students, is deemed necessary.

Parental factors have repeatedly been identified as one of the risk factors for students' alcohol use (reviewed in [27]). The positive link between maternal and paternal alcohol use behaviors was associated with alcohol drinking in adolescents [28]. Parents have also been identified as a source of alcoholic beverages for their children, which can increase the subsequent risky drinking (reviewed in [29]). The alcohol supply by parents, which includes using alcohol in the presence of the children, was associated with an increase in the number of cases of alcohol consumption in children and its impact was more significant on younger children, especially girls, compared to adolescents [30]. School information campaigns moderated the relationship between adolescent binge drinking and parental consumption [22], not peer consumption, indicating a likely high influence of parental alcohol consumption on students. Consequently, the prevention programs directed at parents might help to reduce alcohol drinking among children.

Although both preadolescent prevention efforts and parental education seem important for reducing adolescent drinking, there is no available study for such interventions in Japan. Based on the frequently reported association between parental behavior and children's alcohol drinking, we hypothesized that alcohol supply by parents would initiate alcohol drinking in children. We also analyzed the relationship between parents' knowledge of alcohol-related problems on youth and their alcohol supply.

\section{Materials and Methods}

A total of 420 parents of children in one elementary school (6-12 years old) and three kindergartens (5-6 years old) in Yokohama, Japan, an urban area neighboring the Tokyo metropolitan area, were recruited to participate in the study. The parents of the students in the four schools were notified about the study through the teachers. To ensure anonymity and security, no online tools were used in this study. Thereafter, a paper-based self-administered questionnaire was delivered to the 420 parents of the students. Of this figure, 339 parents ( $n=172$ parents of kindergarteners and 167 parents of elementary students) returned the filled and completed questionnaires (response rate: $81 \%$ ). The completed questionnaires were placed in an envelope to ensure anonymity along with parents' written informed consent, and then parents were required to post them to boxes at these schools. The questionnaire sheet and written informed consent were anonymized. The data manager separated them and the data analyst analyzed the anonymized data. The study was approved by the Institutional Review Board of Yokohama Soei University (No. 27-010).

In the questionnaire, participants were asked to fill in the following information: parent's sex and age (male/female; 20s, 30s, 40s, 50s, and 60s or more) and whether their 
children are in elementary school or kindergarten. The parents were asked a binary variable (yes/no) question concerning their provision of alcoholic beverages to their children. Since underage alcohol drinking is commonly known as illegal in Japan, to prevent parents' concerns about disclosing this information, we did not provide the details regarding this question; that is, the information concerning the frequency and volume of alcohol beverages supplied to children was not included. The answers that enable us to identify the responder were also eliminated, as well as any other type of identifying information.

Parents' knowledge of the health effects of alcohol drinking on youth was determined using nine items. These items were selected from previous studies [31,32]. Participants were asked to check all that they believed to be true (i.e., multiple answers were allowed): (1) Drinking prevents appropriate physical growth and disturbs the homeostasis of sex hormones. (2) A large quantity of alcohol induces acute alcoholism. (3) Drinking induces brain malfunctioning (e.g., memory problems). (4) Drinking induces deterioration of the stomach lining. (5) Drinking frequently induces liver diseases such as hepatitis and cirrhosis. (6) Drinking induces pancreatic diseases such as pancreatitis and diabetes. (7) Excessive alcohol drinking sometimes induces death. (8) Alcohol drinking is addictive. (9) Alcoholism or alcohol addiction is associated with personality disorders.

Parents' perceived requirements for alcohol prevention programs for elementary students were assessed using six items selected from a previous survey conducted in Japan [33]. Again, participants had to select all that they believed applied: (1) Lecture on the effects of drinking on the health of youths. (2) Lecture on the process of developing alcoholism. (3) Lecture on the laws regarding youth alcohol intake. (4) Presentations by alcoholics on their alcoholism experiences. (5) Investigation of the effects of drinking on the physical constitution. (6) Establishment of a consultation center on drinking.

We examined differences between the parents of elementary school students and kindergarten students on their knowledge of the effects of alcohol on youths and their perceived requirements for the alcohol prevention program. The chi-square test was used to assess age differences, and Fisher's exact test was used for all other items, including responses for the main variables. Logistic regression analysis was used to calculate odds ratios and $95 \%$ confidential intervals (CIs) of odds ratios (OR) for all variables for parents of elementary school students compared to the parents of kindergarteners. $p$-values were adjusted by false discovery rate (Benjamini, Kreiger, and Yekutieli) to yield Q-values, considering the multiple independent tests. P-values were adjusted among the items of parents' knowledge of the health effects of alcohol drinking and the items of requirements for the alcohol drinking prevention programs, respectively. All analyses were conducted using GraphPad Prism (ver. 7.0.03, GrapPad Software Inc., San Diego, CA, USA).

\section{Results}

Table 1 shows the parents' general characteristics. The results showed no significant difference in sex $(p=0.93)$ between the groups. There was a significant age difference ( $p<0.0001$, chi-square test) between the groups: mode - the largest proportion of parents of kindergarteners and elementary school students was in their 30s $(n=107,62.2 \%)$ and $40 \mathrm{~s}(n=111,66.5 \%)$, respectively; thus, the latter group was generally older, as expected.

Table 2 summarizes participants' responses for the main variables and compares them between the child groups. Only two parents of kindergarteners had experience in initiating drinking in their children $(1.2 \%)$, whereas nearly all parents of elementary school students $(n=161,96.4 \%)$ had such an experience. This difference was significant $(p<0.0001)$.

We observed no significant group differences in parents' responses to the nine items evaluating their knowledge of the health effects of alcohol drinking on youth. The odds ratios (ORs) ranged from 0.80 to 1.6. Among the nine items, "(2) Large quantity of drinking induces acute alcoholism" garnered the highest responses among both parents of kindergarteners $(n=164,94.2 \%)$ and parents of elementary school students $(n=160$, $95.8 \%, \mathrm{OR}=0.71,95 \% \mathrm{CI}$ (confidence interval): $0.26-1.9$ ). More than $80 \%$ of both groups reported knowledge of “(7) Excessive drinking sometimes induces death" (OR = 1.1, 
95\% CI: 0.62-2.1) and "(8) Drinking is addictive," (OR = 0.91, 95\% CI: 0.5-1.6), while less than $50 \%$ of these parents knew that "(4) Drinking induces deterioration of the stomach lining" (OR $=1.1,95 \%$ CI: 0.73-1.7) and "(6) Drinking induces pancreatic disease such as pancreatitis and diabetes" (OR $=0.80,95 \%$ CI: 0.52-1.2).

As for the six items concerning parents' requirements for drinking prevention programs, we observed significant differences in four items between the parent groups: "(1) Lectures on effects of drinking on youth health" $(p=0.00090, Q=0.0027, \mathrm{OR}=5.4$, $95 \%$ CI: 1.8-16), "(3) Lectures on laws regarding youth drinking" $(p<0.0001, Q=0.00060$ $\mathrm{OR}=2.9,95 \%$ CI: 1.9-4.5), "(4) Presentations by alcoholics on their alcoholism experiences" ( $p=0.0066, \mathrm{Q}=0.013, \mathrm{OR}=1.8,95 \% \mathrm{CI}: 1.2-2.8)$, and "(6) Establishment of a consultation center for drinking" ( $p=0.020, Q=0.030, \mathrm{OR}=2.0,95 \% \mathrm{CI}$ : 1.1-3.5). All these items showed higher demand by the parents of kindergarten children (OR values $\geq 1.0$ ).

Table 3 shows a comparison of parents with or without the experience of initiating their children's drinking. We observed no significant difference in sex $(p=0.86)$, but there was a significant age difference ( $p<0.0001$, chi-square test). Among parents who did not have the initiating experience, those in their 30s were the dominant age group ( $n=106$, $60.2 \%$ ), while among those with such experience, those in their 40 s were the dominant group. We observed no significant difference among the nine knowledge items. As for the requirements of a drinking prevention program, "(3) Prognosis of students with alcohol addiction" ( $p<0.0001)$ showed the greatest difference; items (1), (4), and (6) also showed significant differences $(p<0.05$ and $Q<0.05)$.

Table 1. Characteristics of participants.

\begin{tabular}{|c|c|c|c|c|c|c|}
\hline \multirow{2}{*}{\multicolumn{2}{|c|}{ Characteristic }} & \multicolumn{2}{|c|}{ Kindergarten } & \multicolumn{2}{|c|}{ Elementary School } & \multirow{3}{*}{$p$-Value } \\
\hline & & \multirow{2}{*}{$\begin{array}{c}\boldsymbol{n} \\
172\end{array}$} & \multirow{2}{*}{$\frac{(\%)}{-}$} & \multirow{2}{*}{$\begin{array}{c}n \\
167\end{array}$} & \multirow{2}{*}{$\begin{array}{c}(\%) \\
-\end{array}$} & \\
\hline Total & - & & & & & \\
\hline & Male & 18 & $(10)$ & 18 & (11) & 0.93 \\
\hline Sex & Female & 154 & (90) & 149 & $(89)$ & \\
\hline \multirow{5}{*}{ Age } & $20 s$ & 15 & $(8.72)$ & 6 & $(3.59)$ & $<0.0001^{* * *}$ \\
\hline & $30 \mathrm{~s}$ & 107 & $(62.2)$ & 42 & $(25.1)$ & \\
\hline & $40 s$ & 45 & $(26.2)$ & 111 & $(66.5)$ & \\
\hline & $50 s$ & 1 & $(0.581)$ & 7 & $(4.19)$ & \\
\hline & 60 s or more & 0 & $(0.00)$ & 1 & $(0.599)$ & \\
\hline
\end{tabular}

Note: ${ }^{* * *} p<0.001$.

Table 2. Comparison of parents of kindergarten and elementary school.

\begin{tabular}{|c|c|c|c|c|c|}
\hline \multicolumn{2}{|r|}{ Item } & $\begin{array}{c}\text { Kindergarten } \\
n(\%)\end{array}$ & $\begin{array}{c}\text { Elementary } \\
\text { School } \\
n(\%)\end{array}$ & $\begin{array}{c}p \text {-Value } \\
\text { (Q-Value) }\end{array}$ & $\begin{array}{c}\text { Odds Ratio } \\
(95 \% \mathrm{CI})\end{array}$ \\
\hline \multicolumn{2}{|r|}{ Total } & 172 & 167 & & \\
\hline \multicolumn{6}{|c|}{ Parental experience of initiation of drinking use in children } \\
\hline \multicolumn{2}{|r|}{ Yes } & $\begin{array}{c}2 \\
(1.20)\end{array}$ & $\begin{array}{c}161 \\
(96.4)\end{array}$ & & 2281 \\
\hline \multicolumn{2}{|r|}{ No } & $\begin{array}{c}170 \\
(98.9)\end{array}$ & $\begin{array}{c}6 \\
(3.60)\end{array}$ & $<0.0001$ & $11,470)$ \\
\hline \multicolumn{6}{|c|}{ Knowledge of the possible effects of youth drinking } \\
\hline 1 & $\begin{array}{l}\text { Drinking prevents physical growth } \\
\text { and disturbs the homeostasis of sex } \\
\text { hormones }\end{array}$ & $\begin{array}{c}140 \\
(81.4)\end{array}$ & $\begin{array}{c}126 \\
(75.4)\end{array}$ & $\begin{array}{c}0.19 \\
(0.80)\end{array}$ & $\begin{array}{c}1.4 \\
(0.85-2.4)\end{array}$ \\
\hline 2 & $\begin{array}{l}\text { A large quantity of drinking induces } \\
\text { acute alcoholism }\end{array}$ & $\begin{array}{c}162 \\
(94.2)\end{array}$ & $\begin{array}{c}160 \\
(95.8)\end{array}$ & $\begin{array}{c}0.62 \\
(0.80)\end{array}$ & $\begin{array}{c}0.71 \\
(0.26-1.9)\end{array}$ \\
\hline
\end{tabular}


Table 2. Cont.

\begin{tabular}{|c|c|c|c|c|c|}
\hline & Item & $\begin{array}{l}\text { Kindergarten } \\
n(\%)\end{array}$ & $\begin{array}{c}\text { Elementary } \\
\text { School } \\
n(\%)\end{array}$ & $\begin{array}{l}p \text {-Value } \\
\text { (Q-Value) }\end{array}$ & $\begin{array}{l}\text { Odds Ratio } \\
(95 \% \mathrm{CI})\end{array}$ \\
\hline 3 & $\begin{array}{c}\text { Drinking induces brain } \\
\text { malfunctioning (e.g., memory } \\
\text { problems) }\end{array}$ & $\begin{array}{c}129 \\
(75.0)\end{array}$ & $\begin{array}{c}128 \\
(76.6)\end{array}$ & $\begin{array}{c}0.80 \\
(0.80)\end{array}$ & $\begin{array}{c}0.91 \\
(0.56-1.5)\end{array}$ \\
\hline 4 & $\begin{array}{l}\text { Drinking induces deterioration of the } \\
\text { stomach lining }\end{array}$ & $\begin{array}{c}87 \\
(50.6)\end{array}$ & $\begin{array}{c}80 \\
(47.9)\end{array}$ & $\begin{array}{c}0.66 \\
(0.80)\end{array}$ & $\begin{array}{c}1.1 \\
(0.73-1.7)\end{array}$ \\
\hline 5 & $\begin{array}{l}\text { Drinking induces liver diseases such } \\
\text { as hepatitis and cirrhosis }\end{array}$ & $\begin{array}{c}135 \\
(78.5)\end{array}$ & $\begin{array}{c}117 \\
(70.1)\end{array}$ & $\begin{array}{l}0.080 \\
(0.72)\end{array}$ & $\begin{array}{c}1.6 \\
(0.95-2.6)\end{array}$ \\
\hline 6 & $\begin{array}{l}\text { Drinking induces pancreatic diseases } \\
\text { such as pancreatitis and diabetes }\end{array}$ & $\begin{array}{c}73 \\
(42.4)\end{array}$ & $\begin{array}{c}80 \\
(47.9)\end{array}$ & $\begin{array}{c}0.33 \\
(0.80)\end{array}$ & $\begin{array}{c}0.80 \\
(0.52-1.2)\end{array}$ \\
\hline 7 & $\begin{array}{l}\text { Excessive drinking sometimes } \\
\text { induces death }\end{array}$ & $\begin{array}{c}148 \\
(86.0)\end{array}$ & $\begin{array}{c}141 \\
(84.4)\end{array}$ & $\begin{array}{c}0.76 \\
(0.80)\end{array}$ & $\begin{array}{c}1.1 \\
(0.62-2.1)\end{array}$ \\
\hline 8 & Drinking is addictive & $\begin{array}{c}144 \\
(83.7)\end{array}$ & $\begin{array}{c}142 \\
(85.0)\end{array}$ & $\begin{array}{c}0.77 \\
(0.80)\end{array}$ & $\begin{array}{c}0.91 \\
(0.50-1.6)\end{array}$ \\
\hline 9 & Alcoholism disturbs personality & $\begin{array}{c}118 \\
(68.6)\end{array}$ & $\begin{array}{c}118 \\
(70.7)\end{array}$ & $\begin{array}{c}0.72 \\
(0.80)\end{array}$ & $\begin{array}{c}0.91 \\
(0.57-1.4)\end{array}$ \\
\hline \multicolumn{6}{|c|}{ Requirements of the drinking prevention program } \\
\hline 1 & $\begin{array}{l}\text { Lectures on effects of drinking on } \\
\text { youth health }\end{array}$ & $\begin{array}{c}168 \\
(97.7)\end{array}$ & $\begin{array}{l}148 \\
(88.6)\end{array}$ & $\begin{array}{l}0.00090^{* * *} \\
\left(0.0027^{* *}\right)\end{array}$ & $\begin{array}{c}5.4 \\
(1.8-16)\end{array}$ \\
\hline 2 & $\begin{array}{c}\text { Lectures on process of alcoholism } \\
\text { development }\end{array}$ & $\begin{array}{l}109 \\
(63.4)\end{array}$ & $\begin{array}{c}98 \\
(58.7)\end{array}$ & $\begin{array}{l}0.44 \\
(0.44)\end{array}$ & $\begin{array}{c}1.2 \\
(0.79-1.9)\end{array}$ \\
\hline 3 & $\begin{array}{c}\text { Lectures on laws regarding youth } \\
\text { drinking }\end{array}$ & $\begin{array}{c}103 \\
(59.9)\end{array}$ & $\begin{array}{c}57 \\
(34.1)\end{array}$ & $\begin{array}{l}<0.0001^{* * *} \\
\left(0.00060^{* * *}\right)\end{array}$ & $\begin{array}{c}2.9 \\
(1.9-4.5)\end{array}$ \\
\hline 4 & $\begin{array}{l}\text { Presentations by alcoholics on their } \\
\text { alcoholism experiences }\end{array}$ & $\begin{array}{c}97 \\
(56.4)\end{array}$ & $\begin{array}{c}69 \\
(41.3)\end{array}$ & $\begin{array}{l}0.0066^{* *} \\
\left(0.013^{*}\right)\end{array}$ & $\begin{array}{c}1.8 \\
(1.2-2.8)\end{array}$ \\
\hline 5 & $\begin{array}{l}\text { Investigation on the effects of } \\
\text { drinking on physical constitution }\end{array}$ & $\begin{array}{c}80 \\
(46.5)\end{array}$ & $\begin{array}{c}69 \\
(41.3)\end{array}$ & $\begin{array}{c}0.38 \\
(0.44)\end{array}$ & $\begin{array}{c}1.2 \\
(0.8-1.9)\end{array}$ \\
\hline 6 & $\begin{array}{l}\text { Establishment of a consultation } \\
\text { center on drinking }\end{array}$ & $\begin{array}{c}40 \\
(23.3)\end{array}$ & $\begin{array}{c}22 \\
(13.2)\end{array}$ & $\begin{array}{c}0.020 * \\
(0.030 *)\end{array}$ & $\begin{array}{c}2.0 \\
(1.1-3.5)\end{array}$ \\
\hline
\end{tabular}

Note, CI: confidence interval of the odds ratio. ${ }^{*} p<0.05,{ }^{* *} p<0.01$, and ${ }^{* * *} p<0.001$ for both $p$-values and Q-values.

Table 3. Comparison of parents with/without the experience of initiating alcohol drinking in their children.

\begin{tabular}{|c|c|c|c|c|c|}
\hline & Item & $\begin{array}{c}\text { With } \\
\text { Experience } \\
n(\%)\end{array}$ & $\begin{array}{c}\text { Without } \\
\text { Experience } \\
n(\%)\end{array}$ & $\begin{array}{c}p \text {-Value } \\
\text { (Q-Value) }\end{array}$ & $\begin{array}{c}\text { Odds Ratio } \\
(95 \% \text { CI })\end{array}$ \\
\hline Total & & 176 & 1163 & & \\
\hline \multicolumn{6}{|c|}{ Knowledge of possible effects of youth drinking } \\
\hline 1 & $\begin{array}{l}\text { Drinking prevents physical growth and } \\
\text { disturbs the homeostasis of sex hormones }\end{array}$ & $\begin{array}{c}142 \\
(80.7)\end{array}$ & $\begin{array}{c}124 \\
(76.1)\end{array}$ & $\begin{array}{c}0.30 \\
(0.80)\end{array}$ & $\begin{array}{c}1.30 \\
(0.78-2.2)\end{array}$ \\
\hline 2 & $\begin{array}{l}\text { Large quantity of drinking induces acute } \\
\text { alcoholism }\end{array}$ & $\begin{array}{c}165 \\
(93.8)\end{array}$ & $\begin{array}{c}157 \\
(96.3)\end{array}$ & $\begin{array}{c}0.28 \\
(0.80)\end{array}$ & $\begin{array}{c}0.57 \\
(0.21-1.6)\end{array}$ \\
\hline 3 & $\begin{array}{l}\text { Drinking induces brain malfunctioning (e.g., } \\
\text { memory problems) }\end{array}$ & $\begin{array}{c}131 \\
(74.4)\end{array}$ & $\begin{array}{c}126 \\
(77.3)\end{array}$ & $\begin{array}{c}0.54 \\
(0.80)\end{array}$ & $\begin{array}{c}0.85 \\
(0.52-1.4)\end{array}$ \\
\hline 4 & $\begin{array}{c}\text { Drinking induces deterioration of the } \\
\text { stomach lining }\end{array}$ & $\begin{array}{c}87 \\
(49.4)\end{array}$ & $\begin{array}{c}80 \\
(49.1)\end{array}$ & $\begin{array}{c}0.95 \\
(0.80)\end{array}$ & $\begin{array}{c}1.0 \\
(0.66-1.6)\end{array}$ \\
\hline 5 & $\begin{array}{c}\text { Drinking induces liver diseases such as } \\
\text { hepatitis and cirrhosis }\end{array}$ & $\begin{array}{l}136 \\
(77.3)\end{array}$ & $\begin{array}{l}116 \\
(71.2)\end{array}$ & $\begin{array}{c}0.20 \\
(0.72)\end{array}$ & $\begin{array}{c}1.4 \\
(0.84-2.2)\end{array}$ \\
\hline 6 & $\begin{array}{l}\text { Drinking induces pancreatic diseases such as } \\
\text { pancreatitis and diabetes }\end{array}$ & $\begin{array}{c}73 \\
(41.5)\end{array}$ & $\begin{array}{c}80 \\
(49.1)\end{array}$ & $\begin{array}{c}0.16 \\
(0.80)\end{array}$ & $\begin{array}{c}0.74 \\
(0.48-1.1)\end{array}$ \\
\hline 7 & Excessive drinking sometimes induces death & $\begin{array}{c}149 \\
(84.7)\end{array}$ & $\begin{array}{c}140 \\
(85.9)\end{array}$ & $\begin{array}{c}0.75 \\
(0.80)\end{array}$ & $\begin{array}{c}0.91 \\
(0.5-1.7)\end{array}$ \\
\hline 8 & Drinking is addictive & $\begin{array}{c}147 \\
(83.5)\end{array}$ & $\begin{array}{c}139 \\
(85.3)\end{array}$ & $\begin{array}{c}0.66 \\
(0.80)\end{array}$ & $\begin{array}{c}0.87 \\
(0.49-1.6)\end{array}$ \\
\hline
\end{tabular}


Table 3. Cont

\begin{tabular}{|c|c|c|c|c|c|}
\hline & Item & $\begin{array}{c}\text { With } \\
\text { Experience } \\
\quad n(\%)\end{array}$ & $\begin{array}{c}\text { Without } \\
\text { Experience } \\
n(\%)\end{array}$ & $\begin{array}{c}p \text {-Value } \\
\text { (Q-Value) }\end{array}$ & $\begin{array}{l}\text { Odds Ratio } \\
\text { (95\% CI) }\end{array}$ \\
\hline 9 & $\begin{array}{l}\text { Alcoholism disturbs } \\
\text { personality }\end{array}$ & $\begin{array}{c}121 \\
(68.8)\end{array}$ & $\begin{array}{c}115 \\
(70.6)\end{array}$ & $\begin{array}{c}0.72 \\
(0.80)\end{array}$ & $\begin{array}{c}0.92 \\
(0.58-1.5)\end{array}$ \\
\hline \multicolumn{6}{|c|}{ Requirements of the drinking prevention program } \\
\hline 1 & $\begin{array}{l}\text { Lecture on effects of } \\
\text { drinking on youth health }\end{array}$ & $\begin{array}{c}169 \\
(96.0)\end{array}$ & $\begin{array}{c}147 \\
(90.2)\end{array}$ & $\begin{array}{c}0.033 * \\
(0.049 *)\end{array}$ & $\begin{array}{c}2.6 \\
(1.1-6.6)\end{array}$ \\
\hline 2 & $\begin{array}{l}\text { Lecture on process of } \\
\text { alcoholism development }\end{array}$ & $\begin{array}{c}110 \\
(62.5)\end{array}$ & $\begin{array}{c}97 \\
(59.5)\end{array}$ & $\begin{array}{c}0.57 \\
(0.57)\end{array}$ & $\begin{array}{c}1.1 \\
(0.73-1.8)\end{array}$ \\
\hline 3 & $\begin{array}{l}\text { Lecture on laws regarding } \\
\text { youth drinking }\end{array}$ & $\begin{array}{c}103 \\
(58.5)\end{array}$ & $\begin{array}{c}57 \\
(35.0)\end{array}$ & $\begin{array}{c}<0.0001 \\
(0.00060)\end{array}$ & $\begin{array}{c}2.6 \\
(1.7-4.1)\end{array}$ \\
\hline 4 & $\begin{array}{c}\text { Presentations by alcoholics } \\
\text { on their alcoholism } \\
\text { experiences }\end{array}$ & $\begin{array}{c}98 \\
(55.7)\end{array}$ & $\begin{array}{c}68 \\
(41.7)\end{array}$ & $\begin{array}{l}0.010^{* *} \\
\left(0.031^{*}\right)\end{array}$ & $\begin{array}{c}1.755 \\
(1.1-2.7)\end{array}$ \\
\hline 5 & $\begin{array}{c}\text { Investigation on the effects } \\
\text { of drinking on physical } \\
\text { constitution }\end{array}$ & $\begin{array}{c}81 \\
(46.0)\end{array}$ & $\begin{array}{c}68 \\
(41.7)\end{array}$ & $\begin{array}{c}0.42 \\
(0.51)\end{array}$ & $\begin{array}{c}1.2 \\
(0.77-1.8)\end{array}$ \\
\hline 6 & $\begin{array}{c}\text { Establishment of a } \\
\text { consultation center on } \\
\text { drinking }\end{array}$ & $\begin{array}{c}40 \\
(22.7)\end{array}$ & $\begin{array}{c}22 \\
(13.5)\end{array}$ & $\begin{array}{c}0.028 * \\
(0.049 *)\end{array}$ & $\begin{array}{c}1.9 \\
(1.1-3.3)\end{array}$ \\
\hline
\end{tabular}

Note: ${ }^{*} p<0.05$ and ${ }^{* *} p<0.01$ for both $p$-values and Q-values.

\section{Discussion}

Here, we analyzed the drinking initiation induced by parents for elementary school children and kindergarten and the association of this initiation with parental knowledge regarding youth alcohol drinking. One of the difficulties in this line of research is assuring the validity of data collected from such young students. Furthermore, research on adolescents has shown that parents are major alcohol suppliers [29]. Given this background, we designed a self-administrated questionnaire to understand parents' knowledge of the health effects of alcohol and their experiences of initiating drinking in their children. We also analyzed parents' requests to provide data for designing effective prevention programs.

The most profound difference between the parents of elementary school students and kindergarteners was their experience of initiating their children's drinking; that is, very few parents of kindergarteners had such initiation experiences $(1.16 \%)$ while nearly all parents of elementary school students had such experiences (96.41\%). Meanwhile, no significant differences were observed in alcohol-related knowledge. Therefore, initiation experiences seem to be more dependent on children's age than on parents' knowledge. These initiation experiences were pervasive regardless of elementary school students' age, so it seems that proceeding to elementary school ( 5 or 6 years old) is a clear borderline for initiation experiences.

A survey among Japanese students showed that students who initiated alcohol drinking and cigarette smoking at 12 years of age or less showed greater rates of dependency or addiction to these substances at 15 years of age or older [24]. As noted earlier, 96.4\% of the parents of elementary school students had the experience of initiating alcohol drinking in their children. Parental communication and socialization can influence children's susceptibility to alcohol use initiation; that is, talking with elementary school children about harmful consequences of alcohol use reduced the children's susceptibilities in the family where the parent drank frequently [34]. Independent reports collected from the father, mother, and children each revealed that maternal alcohol abuse was associated with attention and conduct problems observed in adolescent children [35]. These findings indicated the importance of appropriate education on alcohol drinking among parents of students to prevent drinking. Notably, however, we found no difference in parents' knowledge between the groups. In Japan, sake (rice wine) has been considered as not just alcohol but also a mysterious beverage and used for various purposes, including, for example, the 
agreement of pledge of brothers between leaders of different groups by their simultaneous drinking [36]. Especially in the region of Shinto, sake is supplied in various situations, such as shrine festivals and wedding ceremonies [37]. These might weaken the perceived health risks of alcohol for both parents and children. Furthermore, since the initiation was caused by parents, children were given access to alcohol without a sense of immorality. This situation is rather different from parental problem drinking [27,34,35,38-40]. From our result, a high proportion of parents of elementary school students have experience of providing alcohol to their offspring, which indicates that the education of parents is essential. It might be necessary to investigate more carefully the communication strategies between parents and children, which were identified as influential factors for children's alcohol-drinking behaviors [34].

It is increasingly difficult to obtain accurate data from elementary school students and kindergarteners using self-reported questionnaires because of their limited ability to respond to the questions. Therefore, we analyzed parents' data instead. We found that parents' knowledge did not differ according to their experience of initiating alcohol drinking in children. One possible reason is that the data were collected in an urban area close to Tokyo, where most of the residents have similar and high levels of education and economic backgrounds. The current results might not be generalizable to the provincial area, including families with more heterogeneous backgrounds. In addition, based on the extremely high occurrence of parents of elementary school students providing alcoholic beverages to them, the parents without this experience might not be concerned with legal limitations but instead may consider the impacts of drinking on their children's health; in other words, these parents might regard their children who grew up as elementary school students to be strong enough to resist the drinking of alcohol.

Participants' requirements for drinking prevention programs differed according to their children's school. We might consider their required contents as parents' demands for specific knowledge. Thus, the selected items could contribute to the design of parental education programs, which could help to reduce the initiation of children's alcohol usage. While school programs are known to be more effective for managing problematic behaviors among students in Japan (e.g., drinking prevention) when compared to neighborhood programs, the parents were not included in the comparisons [41]. However, the importance of parental education was not evaluated in our study.

This study has several limitations. First, we collected data only in urban areas of Japan, and the sample size was small. In Japan, the constitutive members of a family and cultural events, such as festivals and ceremonial occasions, differ widely between urban and rural areas, and these factors might affect the initiation of alcohol drinking. A larger sample collected from various regions of Japan (both urban and rural) is necessary to evaluate the generalizability of our findings. Second, we hypothesized that parental knowledge would influence the initiation of alcohol drinking and administered the questionnaire only to parents of elementary school students and kindergarteners. Therefore, other factors that affect the initiation of alcohol drinking were not explored. Thirdly, all questionnaires were designed as binary questions, with no dummy or test questions. One of the major problems of this study is that parents are the source of the information even though the questions include inducing their children to illegal alcohol drinking. The quantitative value (e.g., the amount of alcohol supply) was not determined. The different effect of parental and maternal alcohol use on children was reported; for example, paternal drinking showed a higher association of male adolescents rather than maternal drinking [42]. That difference was not found in female adolescents, and this study also showed a high link of peer drinking [42]. Our data included fewer male parents, which possibly causes a bias of the observed association. We were concerned about the low response of this study since the alcohol supply is an explicitly problematic behavior to induce illegal drinking. Thus, we did not include the questions to provide detailed family attributes. However, this simplified questionnaire limits the relative relationship of the other factors to induce children's alcohol drinking. 


\section{Conclusions}

In conclusion, this study investigated the differences in parents' experience of initiating alcohol use in their children. Parents of elementary school children, in general, had experience in initiating alcohol drinking in their children, whereas parents of kindergartners rarely had such an experience. We also investigated young people's knowledge of alcohol drinking and found no significant difference between the two parent groups, suggesting that the age of the children is the only factor. The elementary school students reported a significantly greater number of requirements for drinking prevention programs. Taken together, effective education, especially for parents of elementary school children, is necessary.

Author Contributions: Conceptualization, K.E.; methodology, M.S.; investigation, K.E.; resources, K.E.; writing — original draft preparation, M.S.; writing — review and editing; funding acquisition, K.E. All authors have read and agreed to the published version of the manuscript.

Funding: This research was funded by a JSPS KAKENHI (16K12321).

Institutional Review Board Statement: The study was conducted according to the guidelines of the Declaration of Helsinki and approved by the Institutional Review Board (or Ethics Committee) of Yokohama Soei University (protocol code 27-010).

Informed Consent Statement: Informed consent was obtained from all subjects involved in the study.

Data Availability Statement: The data that support the findings of this study are available from the corresponding author, M.S., upon reasonable request.

Acknowledgments: We thank the teachers who cooperated with this study at the elementary school and kindergartens in Yokoyama.

Conflicts of Interest: The authors declare no conflict of interest.

\section{References}

1. Gore, F.M.; Bloem, P.J.; Patton, G.C.; Ferguson, J.; Joseph, V.; Coffey, C.; Sawyer, S.M.; Mathers, C.D. Global Burden of Disease in Young People Aged 10-24 Years: A Systematic Analysis. Lancet 2011, 377, 2093-2102. [CrossRef]

2. Patrick, M.E.; Schulenberg, J.E. Prevalence and Predictors of Adolescent Alcohol Use and Binge Drinking in the United States. Alcohol Res. Curr. Rev. 2013, 35, 193-200.

3. Hingson, R.; Heeren, T.; Winter, M.R.; Wechsler, H. Early Age of First Drunkenness as a Factor in College Students' Unplanned and Unprotected Sex Attributable to Drinking. Pediatrics 2003, 111, 34-41. [CrossRef]

4. Hingson, R.W.; Heeren, T.; Jamanka, A.; Howland, J. Age of Drinking Onset and Unintentional Injury Involvement after Drinking. JAMA 2000, 284, 1527-1533. [CrossRef] [PubMed]

5. Peltzer, K.; Pengpid, S. Early Substance Use Initiation and Suicide Ideation and Attempts Among School-Aged Adolescents in Four Pacific Island Countries in Oceania. Int. J. Environ. Res. Public Health 2015, 12, 12291-12303. [CrossRef] [PubMed]

6. Forman-Hoffman, V.L.; Edlund, M.; Glasheen, C.; Ridenour, T. Alcohol Initiation and Progression to Use, Heavy Episodic Use, and Alcohol Use Disorder among Young Adolescents Ages 12-14 Living in U.S. Households. J. Stud. Alcohol Drugs 2017, 78, 853-860. [CrossRef]

7. Hong, S.A.; Peltzer, K. Early Adolescent Patterns of Alcohol and Tobacco Use in Eight Association of South-East Asian Nations (ASEAN) Member States. Subst. Use Misuse 2019, 54, 288-296. [CrossRef]

8. Hung, C.C.; Chang, H.Y.; Chiang, Y.C.; Wu, W.C.; Yen, L.L. Factors Associated With Levels of Risky Drinking in Adolescent Alcohol Users in Taiwan: A Secondary Data Analysis. J. Nurs. Res. 2017, 25, 163-172. [CrossRef]

9. Rongkavilit, C.; Naar-King, S.; Chuenyam, T.; Wang, B.; Wright, K.; Phanuphak, P. Health Risk Behaviors Among HIV-Infected Youth in Bangkok, Thailand. J. Adolesc. Health 2007, 40, 358.e1-358.e8. [CrossRef]

10. Lu, S.; Du, S.; Hu, X.; Zou, S.; Liu, W.; Ba, L.; Ma, G. Drinking Patterns and the Association Between Socio-Demographic Factors and Adolescents' Alcohol Use in Three Metropolises in China. Int. J. Environ. Res. Public Health 2015, 12, 2037-2053. [CrossRef]

11. Lee, C.K.; Corte, C.; Stein, K.F. Drinker Identity: Key Risk Factor for Adolescent Alcohol Use. J. Sch. Health 2018, 88, 253-260. [CrossRef]

12. Deas, D.; Riggs, P.; Langenbucher, J.; Goldman, M.; Brown, S. Adolescents Are Not Adults: Developmental Considerations in Alcohol Users. Alcohol. Clin. Exp. Res. 2000, 24, 232-237. [CrossRef]

13. Mattila, V.M.; Parkkari, J.; Lintonen, T.; Kannus, P.; Rimpelä, A. Occurrence of Violence and Violence-Related Injuries Among 12-18 Year-Old Finns. Scand. J. Public Health 2005, 33, 307-313. [CrossRef]

14. Swahn, M.H.; Bossarte, R.M.; Sullivent, E.E., 3rd. Age of Alcohol Use Initiation, Suicidal Behavior, and Peer and Dating Violence Victimization and Perpetration Among High-Risk, Seventh-Grade Adolescents. Pediatrics 2008, 121, 297-305. [CrossRef] 
15. Wang, C.; Hipp, J.R.; Butts, C.T.; Lakon, C.M. The Interdependence of Cigarette, Alcohol, and Marijuana Use in the Context of School-Based Social Networks. PLoS ONE 2018, 13, e0200904. [CrossRef]

16. Agrawal, A.; Lynskey, M.T. Tobacco and Cannabis Co-Occurrence: Does Route of Administration Matter? Drug Alcohol Depend. 2009, 99, 240-247. [CrossRef] [PubMed]

17. Takakura, M.; Nagayama, T.; Sakihara, S.; Willcox, C. Patterns of Health-Risk Behavior Among Japanese High School Students. J. Sch. Health 2001, 71, 23-29. [CrossRef]

18. Peleg-Oren, N.; Saint-Jean, G.; Cardenas, G.A.; Tammara, H.; Pierre, C. Drinking alcohol before age 13 and negative outcomes in late adolescence. Alcohol. Clin. Exp. Res. 2009, 33, 1966-1972. [CrossRef] [PubMed]

19. Kim, H.H.; Chun, J. Analyzing Multilevel Factors Underlying Adolescent Smoking Behaviors: The Roles of Friendship Network, Family Relations, and School Environment. J. Sch. Health 2018, 88, 434-443. [CrossRef] [PubMed]

20. Merrill, J.C.; Kleber, H.D.; Shwartz, M.; Liu, H.; Lewis, S.R. Cigarettes, Alcohol, Marijuana, Other Risk Behaviors, and American Youth. Drug Alcohol Depend. 1999, 56, 205-212. [CrossRef]

21. Moritsugu, K.P. Underage Drinking: A Call to Action. J. Am. Diet. Assoc. 2007, 107, 1464. [CrossRef]

22. Rodriguez-Sanchez, C.; Sancho-Esper, F.; Casaló, L.V. Understanding Adolescent Binge Drinking in Spain: How School Information Campaigns Moderate the Role of Perceived Parental and Peer Consumption. Health Educ. Res. 2018, 33, 361-374. [CrossRef]

23. Sussman, S.; Arriaza, B.; Grigsby, T.J. Alcohol, Tobacco, and Other Drug Misuse Prevention and Cessation Programming for Alternative High School Youth: A Review. J. Sch. Health 2014, 84, 748-758. [CrossRef]

24. Takakura, M.; Wake, N. Association of Age at Onset of Cigarette and Alcohol Use With Subsequent Smoking and Drinking Patterns Among Japanese High School Students. J. Sch. Health 2003, 73, 226-231. [CrossRef] [PubMed]

25. Takakura, M.; Wake, N.; Kobayashi, M. The Contextual Effect of School Satisfaction on Health-Risk Behaviors in Japanese High School Students. J. Sch. Health 2010, 80, 544-551. [CrossRef]

26. Donovan, J.E.; Leech, S.L.; Zucker, R.A.; Loveland-Cherry, C.J.; Jester, J.M.; Fitzgerald, H.E.; Puttler, L.I.; Wong, M.M.; Looman, W.S. Really Underage Drinkers: Alcohol Use Among Elementary Students. Alcohol. Clin. Exp. Res. 2004, 28, 341-349. [CrossRef] [PubMed]

27. Sharmin, S.; Kypri, K.; Khanam, M.; Wadolowski, M.; Bruno, R.; Attia, J.; Holliday, E.; Palazzi, K.; Mattick, R.P. Effects of Parental Alcohol Rules on Risky Drinking and Related Problems in Adolescence: Systematic Review and Meta-Analysis. Drug Alcohol Depend. 2017, 178, 243-256. [CrossRef]

28. Latendresse, S.J.; Rose, R.J.; Viken, R.J.; Pulkkinen, L.; Kaprio, J.; Dick, D.M. Parenting Mechanisms in Links Between Parents' and Adolescents' Alcohol Use Behaviors. Alcohol. Clin. Exp. Res. 2008, 32, 322-330. [CrossRef] [PubMed]

29. Sharmin, S.; Kypri, K.; Khanam, M.; Wadolowski, M.; Bruno, R.; Mattick, R.P. Parental Supply of Alcohol in Childhood and Risky Drinking in Adolescence: Systematic Review and Meta-Analysis. Int. J. Environ. Res. Public Health 2017, 14, 287. [CrossRef] [PubMed]

30. Strandberg, A.K.; Bodin, M.C.; Romelsjö, A. Gender Differences in the Prediction of Parental Servings of Alcohol to Adolescents and Youth Drunkenness. Subst. Use Misuse 2014, 49, 1857-1866. [CrossRef] [PubMed]

31. Eto, K. Drinking Knowledge and Attitude of Parents Who Have Elementary-Aged Child. Jpn. J. Study Addict. Nurs. 2014, 11, 2-6. (In Japanese)

32. Eto, K.; Matsushita, T. Background of Alcohol Abuse in Youth Period: The Self-Administered Questionnaires Survey of Problem Drinkers in Junior-High School Students. Jpn. J. Study Addict. Nurs. 2012, 9, 2-8. (In Japanese)

33. Wada, K. Prevalence of Solvent Inhalation Among Junior High School Students in Japan and Their Background Lifestyle: Results of Chiba Prefecture Survey in 1992. Jpn. J. Sch. Health 2001, 43, 26-38. (In Japanese)

34. Ennett, S.T.; Jackson, C.; Bowling, J.M.; Dickinson, D.M. Parental Socialization and Children's Susceptibility to Alcohol Use Initiation. J. Stud. Alcohol Drugs 2013, 74, 694-702. [CrossRef]

35. Torvik, F.A.; Rognmo, K.; Ask, H.; Røysamb, E.; Tambs, K. Parental Alcohol Use and Adolescent School Adjustment in the General Population: Results From the HUNT Study. BMC Public Health 2011, 11, 706. [CrossRef] [PubMed]

36. Rath, E. Food and Fantasy in Early Modern Japan; University of California Press: Berkeley, CA, USA, 2010.

37. Ashkenazi, M.; Jacob, J. Food Culture in Japan; Greenwood Publishing Group: Westport, CT, USA, 2003 ; Volume 1.

38. Belles, S.; Budde, A.; Moesgen, D.; Klein, M. Parental Problem Drinking Predicts Implicit Alcohol Expectancy in Adolescents and Young Adults. Addict. Behav. 2011, 36, 1091-1094. [CrossRef] [PubMed]

39. Bowden, J.A.; Delfabbro, P.; Room, R.; Miller, C.; Wilson, C. Parental Drinking in Australia: Does the Age of Children in the Home Matter? Drug Alcohol Rev. 2019, 38, 306-315. [CrossRef] [PubMed]

40. Rossow, I.; Keating, P.; Felix, L.; McCambridge, J. Does Parental Drinking Influence Children's Drinking? A Systematic Review of Prospective Cohort Studies. Addiction 2016, 111, 204-217. [CrossRef]

41. Takakura, M.; Miyagi, M.; Ueji, M.; Kobayashi, M.; Kurihara, A.; Kyan, A. The Relative Association of Collective Efficacy in School and Neighborhood Contexts With Adolescent Alcohol Use. J. Epidemiol. 2019, 29, 384-390. [CrossRef]

42. Kuo, P.C.; Huang, J.H.; Wu, S.C.; Chen, W.J. Associations of Parental and Peer Cross-Substance Use With 12-17-Year-Old Adolescents' Problematic Alcohol Use: A Parent/Child Dyadic Gender Analysis. Drug Alcohol Depend. 2021, $221,108611$. [CrossRef] [PubMed] 